\title{
Transitivitas dalam Teks Peradilan Indonesia: Kajian Linguistik Fungsional Sistemik
}

\author{
Transtivity in Indonesia Court Trial Text: Systemic Functional \\ Linguistics Perspective
}

\author{
Nidya Fitri ${ }^{1{ }^{1 *}}$, Ketut Artawa ${ }^{2}$, Made Sri Satyawati ${ }^{3}$, dan Sawirman ${ }^{4}$ \\ ${ }^{1}$ STITNU Sakinah Dharmasraya \\ ${ }^{2,3}$ Universitas Udayana \\ ${ }^{4}$ Universitas Andalas \\ ${ }^{1}$ Corresponding email: nidya.fitri85@gmail.com \\ ${ }^{2}$ Email: tutartawa@gmail.com \\ ${ }^{3}$ Email: srisatyawati@gmail.com \\ ${ }^{4}$ Email: drsawirman@gmail.com
}

\begin{abstract}
This article analyzes transitivity in Indonesian judicial texts, particularly Jessica-Mirna's judicial texts. Functional Systemic Linguistic (FSL) theory is used as an analytical tool. The data were collected through document recording with a qualitative descriptive method through the trial process from YouTube. The results of the trial process were transcribed into written data in the form of text. The data were analyzed in stages, namely, (1) classification of judicial text based on the content of the text; (2) text characteristics; (3) analysis using the LSF model. The results showed that the material process was obtained as much as 5,822 (45\%) as the first order. The second place is occupied by mental processes obtained as much as 2,064 (15\%). The third place is occupied by the forming process, obtained as much as 1,616 (11\%). Based on the results of this study, the actions and deeds of the perpetrator were realized through the transitivity of Jessica-Mirna's judicial texts.

Keywords: transitivity, judicial text, systemic functional linguistics
\end{abstract}

\begin{abstract}
Abstrak: Artikel ini menganalisis transitivitas di dalam teks peradilan Indonesia, khususnya teks peradilan Jessica-Mirna. Teori Linguistik Sistemik Fungsional (LSF) digunakan sebagai alat analisis. Data dikumpulkan melalui pencatatan dokumen dengan metode deskriptif kualitatif melalui proses persidangan dari you tube. Hasil proses persidangan ditranskripsikan ke dalam data tulis dengan berbentuk teks. Data dianalisis dilakukan dengan tahapan, yaitu (1) klasifikasi teks peradilan berdasarkan isi teks; (2) karakteristik teks; (3) analisis dengan menggunakan model LSF. Hasil penelitian menunjukkan bahwa proses material diperoleh sebanyak $5.822(45 \%)$ sebagai urutan pertama. Urutan kedua ditempati oleh proses mental diperoleh sebanyak 2.064 (15\%). Urutan ketiga ditempati oleh proses wujud diperoleh sebanyak $1.616(11 \%)$. Berdasarkan hasil penelitian ini mengidentifikasi bahwa adanya tindakan dan perbuatan pelaku yang direalisasikan melalui transitivitas teks peradilan Jessica-Mirna.
\end{abstract}

Kata kunci: transtivitas, teks peradilan, sistemik fungsional linguistik

To cite this article:

Fitri, N., Artawa, K., Satyawati, M. S., \& Sawirman. (2021). Transitivitas dalam Teks Peradilan Indonesia: Kajian Linguistik Fungsional Sistemik. Diglosia: Jurnal Kajian Bahasa, Sastra, dan Pengajarannya, 4(2), 139-148. https://doi.org/10.30872/diglosia.v4i2.116 


\section{A. PENDAHULUAN}

Salah satu kasus yang menarik perhatian media adalah kasus Jessica-Mirna karena merupakan isu kontroversial dari tahun 2015 sampai dengan tahun 2016. Kasus Jessica-Mirna yang selanjutnya disebut dengan (KJM) adalah salah satu fenomena dan aktivitas bahasa yang melibatkan aspek hukum dan aspek bahasa. Aspek hukum dan bahasa ini dikenal dengan Linguistik Forensik (LF).

Kasus ini ditayangkan secara langsung dengan melihat interaksi verbal yang melibatkan permainan bahasa di ruang sidang peradilan. Hal ini. disebabkan oleh bahasa merupakan unsur utama di dalam proses penyampaian informasi kepada khalayak ramai, khususnya di media televisi. Tidak hanya sekadar menyampaikan informasi, akan tetapi juga mendidik, menghibur, memengaruhi, memberikan, responsibilitas sosial dan penghubung (Sudarman, 2008). Di dalam interaksi verbal di ruang sidang peradilan pada KJM ini disaksikan secara langsung di media televisi oleh khalayak ramai. Dalam hal ini media tidak hanya menyuguhkan isu-isu dan berita-berita, tetapi juga merupakan penggerak perkembangan keadaban, kebudayaan, dan sudah mendarah daging dalam setiap kebutuhan manusia. Pernyataan sejenis juga diungkapkan oleh (Davis \& Paul, 2010). Menurut mereka ada tiga fase media berdasarkan kebutuhan. Pertama, kondisi institusional dan organisasional serta praktik produksi dengan segala aspek tentang konvensi dan pencitraan sudah diatur dalam kebijakan media itu sendiri. Kedua, teks media yang merupakan konstruksi simbolik, pengaturan, dan produk media dari bentuk kecakapan media, praktik, teknis, dan kebudayaan merupakan bentuk dan isi dari sesuatu yang dipublikasikan dan disiarkan oleh media yang berasal dari pesan dan ide yang dibungkusnya. Ketiga, momen penerimaan konsumsi atau mengodekan oleh para pendengar dan pembaca. Momen penerimaan konsumsi atau mengodekan merupakan sebuah praktik yang melibatkan pendengar dan pembaca dalam memahami dan menyadari lebih dekat dengan bentuk konstruksi dari sebuah teks media.

Berdasarkan pernyataan di atas menyatakan bahwa peran media mengkonstruksi pemberitaan secara simbolik. Konstruksi simbolik tersebut tidak terlepas dari permainan bahasa yang disampaikan oleh Wittgenstein adalah salah satu sosok yang mempopulerkan bahasa sebagai game (Genova, 1978). Permainan bahasa yang dimaksud dapat memengaruhi pendengar dan pembaca sehingga dapat diasumsikan bahwa mengodekan mengkonstruksi berita media tidak dapat dipahami oleh pembaca karena adanya permainan bahasa. Dengan demikian, bahasa media dalam merepresentasikan realitas dengan menggunakan bahasa yang dipenuhi oleh kode-kode simbolik yang digunakan untuk pengaburan makna dalam media. Pengaburan tersebut bida terjadi, baik dalam aspek bunyi, morfosintaksis, leksikal, maupun kalimat.

Kasus ini memiliki keunikan tersendiri jika dipandang dari aspek kelinguistikannya. Bila ditinjau dari aspek akademis, penelitian tentang LF sudah dilakukan pada tahun 1968 oleh Jan Svarrtvik dengan membantu pihak kepolisian dan mampu membuktikan terdakwa divonis hukuman mati menjadi tidak bersalah dengan menjadikan bahasa sebagai alat bukti hukum dalam mengungkap sebuah praktik kejahatan. Kemudian, penelitian LF sudah mengkaji pada bidang ajakan dalam bentuk percakapan, perbandingan hasil rekaman suara dengan tulisan terdakwa, stilistika kepengarangan, bahasa peradilan dan pembuktiannya, kehadiran LF di persidangan, pencemaran nama baik, saksi ahli bahasa sebagai legal proses. 
Kedua, kajian LF sudah banyak mengamati teks hukum sejak tahun 2013. Hasil kajian sudah dilakukan dari segi pragmatik, psikologi, dan psikologi pragmatik. Walaupun penelitian tersebut sudah dilakukan sejak 1968 sampai dengan 2016 yang mendiskusikan tentang LF, namun hasil-hasil penelitian tersebut belum mendiskusikan bagaimana cara mengungkap praktik kejahatan melalui interaksi verbal di ruang sidang peradilan.

Dengan demikian, hasil yang diperoleh tidak membantu pihak kepolisian dan pihak peradilan untuk mengungkap sebuah kasus hukum. Padahal sesungguhnya LF merupakan pengungkapan fakta bahasa yang dikaji dengan pendekatan hukum. Dalam sebuah proses hukum, untuk mengetahui kebenaran atau untuk memvonis hukuman kepada terdakwa akan menggunakan perangkat peradilan seperti penasehat hukum, jaksa penuntut umum, hakim, saksi ahli, dan saksi biasa. Dari beberapa hasil penelitian diketahui bahwa analisis terhadap teks peradilan tidak menekankan pada penggunaan saksi ahli bahasa. Saksi ahli bahasa selama ini dianggap kurang memiliki pengaruh yang signifikan terhadap penilaian hakim dalam mempertimbangkan keputusan. Padahal, saksi ahli bahasa mungkin saja memiliki pengaruh yang signifikan terhadap keputusan pengadilan. Dalam penelitian ini dilakukan pembuktian bahwa saksi ahli bahasa dalam kasus Jessica-Mirna memiliki peranan yang sangat penting sehingga kajian ini akan lebih banyak mengamati interaksi verbal dalam proses sidang peradilan Jessica-Mirna yang dirangkum dalam tayangan proses peradilan Jessica-Mirna dan diperoleh melalui YouTube.

Bila ditinjau dari aspek empiris, pada kasus Jessica-Mirna belum dapat mengungkap pelaku sebenarnya, misalnya menghadirkan saksi ahli hukum pidana dari Universitas Gadjah Mada bernama Prof. Dr. Edward Os Hiariej. Saksi ahli ini mengemukakan bahwa pembunuhan berencana yang dituduhkan pada tersangka tidak membutuhkan motif dalam tindakan yang dilakukannya, sementara saksi ahli bahasa dapat mengatakan bahwa pembunuhan yang dilakukan pelaku memiliki motif. Hal ini dibuktikan dengan pola kebahasaan dibantu dengan gerakan nonverbal tersangka pada saat pemeriksaan di ruang sidang peradilan. Melalui kemunculan pola kebahasaan dan gerakan nonverbal yang diproduksi tersangka dapat dibedah dengan teori Linguistik Sistemik Fungsional (LSF) dan pendekatan Linguistik Forensik (LF) sehingga bisa menentukan bahwa pembunuhan tersebut memiliki motif dan mampu memberikan titik terang dengan mengubah status tersangka menjadi terdakwa. Tujuan Penelitian ini adalah melalui kajian LSF merealisasikan ekspresi dan ide pelibat dalam Bahasa yang diproduksinya di dalam ruang sidang peradilan.

Berdasarkan alasan akademis dan empiris pada uraian tersebut, penelitian ini perlu dilakukan yang bertujuan untuk merealisasikan ekspresi dan ide keterangan saksi ahli dalam proses peradilan sehingga lebih mudah menentukan pelaku dalam kasus Jessica-Mirna.

\section{B. METODE}

Penelitian ini menggunakan metode deskriptif kualitatif karena untuk menggambarkan fenomena sosial dalam proses peradilan, khususnya peradilan Jessica-Mirna (Creswell \& Creswell, 2017). Data dikumpulkan dari hasil proses peradilan berlangsung dari Youtube. Hasil proses persidangan berupa interaksi verbal kemudian ditranskripsikan secara ortografis menjadi data tulis. Analisis data menggunakan teori LSF dengan mengklasifikasikan teks berdasarkan isi dan 
karakteristik teks. Kemudian, hasil analisis disajikan dalam bentuk penjelasan berdasarkan klasifikasi proses dalam teori LSF.

\section{PEMBAHASAN}

\section{Proses Material}

Proses material kegiatan atau kejadian berkaitan dengan fisik dan nyata dilakukan oleh pelakunya serta dapat diamati oleh indera. Proses material ini merupakan semua kegiatan yang terjadi di luar diri manusia. Menurut ciri semantiknya, proses material ini menunjukkan suatu perbuatan yang dilakukan oleh pelaku dan dikenakan pada suatu maujud di luar dirinya (Halliday, 1985). Berikut beberapa contoh proses material memiliki unsur forensik dalam sesi sidang peradilan Jessica-Mirna (SPJM).

Tabel 1. SPJM Sidang 1

\begin{tabular}{cll}
\hline No & Proses Material & Fungsi \\
\hline \multirow{3}{*}{ Data 1 } & (Apakah) Saudara ahli & Aktor \\
& Melakukan & Proses Material: Doing \\
& Analisa & Gol \\
& Terhadap matinya korban Mirna & Sirkumstan: Sebab \\
\hline
\end{tabular}

Data 1 menunjukkan proses material yang perannya sebagai partisipan utama dilabeli aktor. Aktor tersebut membahas tentang apa yang dibicarakan oleh pembicara, seperti saudara ahli. Kedua, proses material ini memiliki tiga klasifikasi verba material, yaitu doing, happaening, dan changing. Verba material doing adalah verba material yang menggambarkan kegiatan yang sedang dilakukan, seperti melakukan. Ketiga, proses material yang perannya sebagai partisipan tambahan dilabeli gol setara fungsinya sebagai objek dalam klausa dan kalimat, seperti analisa

Tabel 2. SPJM Sidang 3

\begin{tabular}{cll}
\hline No & Proses Material & Fungsi \\
\hline \multirow{2}{*}{ Data 2} & $\begin{array}{l}\text { Kedokteran Forensik } \\
\text { (hampir selalu) } \\
\text { ditemukan }\end{array}$ & Gol \\
& Ketidaklengkapan dan keterbatasan & $\begin{array}{l}\text { Proses Material: Changing } \\
\text { Sirkumstan: Cara }\end{array}$ \\
\hline
\end{tabular}

Data 2 menunjukkan klausa pasif sehingga awal kalimat dilabeli gol pada kedokteran dan forensik. Proses material changing mengalami perubahan dari tidak ada menjadi ada, seperti ditemukan. Proses material dilabeli sebagai proses material changing. Sirkumstan fungsinya sebagai keterangan pada ketidaklengkapan dan keterbatasan, sementara klausa di atas tidak memiliki partisipan utama dilabeli aktor.

Tabel 3. SPJM Sidang 9

\begin{tabular}{cll}
\hline No & Proses Material & Fungsi \\
\hline \multirow{3}{*}{ Data 3 } & Saudara & Aktor \\
& (telah pernah) & - \\
& Memeriksa & Proses Material: Happening \\
& Terdakwa sebelumnya & Gol \\
\hline
\end{tabular}


Data 3 menunjukkan proses material happening yang sedang terjadi oleh partisipan utama dilabeli aktor dimaksud adalah saksi ahli mengacu pada kata suadara. Aktor ini dapat setarakan fungsinya sebagai objek. Proses material itu dapat disamakan fungsinya sebagai predikat atau kata kerja dilabeli proses material happening. Partisipan tambahan dilabeli gold an fungsinya dapat disamakan sebagai objek atau pelaku pada kata terdakwa sebelumnya

Berdasarkan tiga klasifikasi proses material, yaitu doing, changing, dan happening. Proses material klasifikasi doing paling dominan ditemukan dalam penelitian ini karena jaksa penuntut umum, hakim, dan penasehat hukum saling menunjukkan upaya mereka dalam menggali informasi melalui aktivitas bahasa dalam sidang peradilan tentang pelaku pembunuhan kopi sianida.

\section{Proses Mental}

Proses mental merupakan kegiatan berkaitan dengan proses merasakan/sensing. Proses ini diklasifikasikan empat kategori, yaitu afeksi/emosi, kognisi, persepsi dan desiderative. Partisipan utama di dalam proses mental dlabeli pengindera. Partisipan tambahan yang dikenai proses dilabeli dengan fenomena (Halliday, 1985). Berikut sejumlah contoh proses mental berdasarkan interaksi verbal dalam SPJM.

\section{Tabel 4. SPJM Sidang 1}

\begin{tabular}{cll}
\hline No & Proses Material & Fungsi \\
\hline \multirow{3}{*}{ Data 4 } & (apakah) & - \\
& Saudara & Pengindera \\
& Tahu & Proses Mental: Kognisi \\
& Bahwa (ada) masuk sianida sebanyak 298mm? & Fenomena \\
\hline
\end{tabular}

Data 4 menunjukkan proses mental memiliki peran partisipan utama pada proses mental dilabeli pengindera. partisipan ini setara fungsinya sebagai subjek pada klausa, seperti saudara. Kedua, proses mental diklasifikasikan menjadi empat verba mental, yaitu afeksi/emosi, kognisi, persepsi, dan desiderative. Verba mental kognisi, seperti tahu. Ketiga, peran partisipan tambahan pada proses mental dilabeli fenomena yang berfungsi sebagai objek, yakni bahwa (ada) masuk sianida sebanyak $298 \mathrm{~mm}$.

Tabel 5. SPJM Sidang 11

\begin{tabular}{|c|c|c|}
\hline No & Proses Material & Fungsi \\
\hline \multirow{4}{*}{ Data 5} & Kita & Pengindera \\
\hline & melihat & Proses Mental: Persepsi \\
\hline & Data koletral itu & Proses Mental: Kognisi \\
\hline & Secara reflek & Sirkumstan: Kualitas \\
\hline
\end{tabular}

Data 5 menunjukkan kata kita berperan sebagai patisipan utama dilabeli pengindera. Proses mental persepsi direalisasikan dengan verba mental kognisi pada kata melihat dilabeli proses mental persepsi. Partisipan tambahan dilabeli fenomena pada kata data koletral itu dapat disamakan fungsinya sebagai objek. Sirkumstan kualitas dapat setrakan fungsinya sebagai keterangan pada klausa di atas. 
Tabel 6. SPJM Sidang 15

\begin{tabular}{|c|c|c|}
\hline No & Proses Material & Fungsi \\
\hline \multirow{4}{*}{ Data 6} & Saya & Pengindera \\
\hline & menilai & Proses Mental: Desiderative \\
\hline & Pendapat ahli & Fenomena \\
\hline & Bagaimana dengan hasil observasi & Sirkumstan: Kualitas \\
\hline
\end{tabular}

Data 6 menunjukkan kata saya berperan sebagai patisipan utama dilabeli pengindera. Proses mental desiderative direalisasikan dengan verba mental desiderative pada kata menilai dilabeli proses mental desiderative. Partisipan tambahan dilabeli fenomena pada kata pendapat ahli itu dan dapat disamakan fungsinya sebagai objek. Sirkumstan kualitas dapat setarakan fungsinya sebagai keterangan pada kata bagaimana dengan hasil observasinya?.

Berdasarkan klasifikasi proses mental yaitu afeksi/emosi, kognisi, persepsi, dan desiderative. Proses mental pada klasifikasi kognisi paling dominan ditemukan karena semua saksi ahli, saksi biasa, dan terdakwa memberikan keterangan sesuai dengan apa yang mereka lihat, dengar, dan rasakan sendiri pada saat pembunuhan terjadi di kafe Olivier (Satyawati, Fitri, Artawa, Sawirman, \& Udayana, 2020).

\section{Proses Wujud}

Proses wujud (existential) merupakan keberadaan suatu wujud. Dalam Bahasa Indonesia proses eksistensial tidak didahului oleh permarkah subjek. Proses wujud "ada" muncul di awal klausa. Proses eksistensial dapat berupa verba, seperti ada, berada, bertahan, muncul, terjadi, tersebar, dan tumbuh. Partisipan dalam klausa proses wujud disebut maujud (existent) (Halliday, 1985; Narlianti, 2015). Dapat dilihat dari contoh di bawah ini.

Tabel 7. SPJM Sidang 1

\begin{tabular}{cll}
\hline No & Proses Material & Fungsi \\
\hline \multirow{2}{*}{ Data 7} & Ini terjadinya & Proses wujud \\
& Rasa pedas dan iritasi & Maujud \\
\hline
\end{tabular}

Data 7 menunjukkan proses wujud tersebut diwujudkan dengan verba wujud, seperti ini terjadinya. Pada proses wujud hanya ada satu partisipan dilabeli maujud. Maujud direalisasikan pada rasa pedas dan iritasi.

\section{Proses Verbal}

Proses verbal adalah aktivitas atau kegiatan berhubungan dengan informasi. Dalam proses verbal terdapat empat partisipan, yaitu partisipan yang menyatakan lisan secara struktural disebut penyampai, maklumat yang disampaikan atau dikatakan disebut perkataan. Orang atau benda yang kepadanya ucapan atau informasi disampaikan atau diarahkan disebut penerima. Entitas yang menjadi target proses verbal disebut sasaran (Halliday, 1985; Narlianti, 2015). 
Tabel 8. SPJM Sidang 1

\begin{tabular}{cll}
\hline No & Proses Material & Fungsi \\
\hline \multirow{3}{*}{ Data 8 } & Saudara & Penyampai \\
& $\begin{array}{l}\text { Menjelaskan } \\
\text { Bahwa riwayat pendidikan saudara sebagai } \\
\text { ahli patologi forensik }\end{array}$ & Proses Verbal \\
& Perkataan \\
\hline
\end{tabular}

Data 8 menunjukkan proses verbal peranya sebagai partisipan utama dilabeli penyampai. Penyampai ini mengacu kepada apa yang dikatakan atau disampaikan dalam proses verbal, seperti saudara. Kedua, proses verbal memiliki verba yang menjelaskan proses itu sendiri, seperti menjelaskan. Ketiga, proses verbal dapat mengikat tiga partisipan lain atau tambahan, yaitu penerima, perkataan, dan sasaran. Ketiga partisipan ini dapat disetarakan fungsinya sebagai objek dalam klausa. Pada data tidak terdapat partisipan lainnya, seperti penerima dan sasaran, hanya partisipan perkataan yang ditemukan, seperti bahwa riwayat pendidikan saudara sebagai ahli patologi forensik. Berdasarkan proses verbal di atas, partisipan penyampai dan perkataan yang ditemukan, sedangkan penerima dan sasaran tidak ditemukan berdasarkan data analisis.

\section{Proses Tingkah Laku}

Proses tingkah laku merupakan aktivitas fisiologis dan psikologi yang menyatakan tingkah laku fisik manusia. Dalam implikasinya proses tingkah laku sebagian memiliki sifat material, sebagian memiliki sifat proses mental, dan sebagian mempunyi sifat proses verbal. Partisipan dalam proses tingkah laku ini dilabeli petingkah laku dan memiliki kesadaran (Halliday, 1985; Narlianti, 2015). Hal ini dapat dilihat dari contoh berikut.

Tabel 9. SPJM Sidang 1

\begin{tabular}{cll}
\hline No & \multicolumn{1}{c}{ Proses Material } & \multicolumn{1}{c}{ Fungsi } \\
\hline \multirow{2}{*}{ Data 9} & Ini terjadinya & Petingkah \\
& Rasa pedas dan iritasi & Proses tingkah: Fisiologis \\
& Sendiri & Sirkumstan \\
\hline
\end{tabular}

Data 9 menunjukkan proses tingkah laku hanya ada satu partisipan adalah petingkah. Petingkah ini setara fungsinya sebagai subjek dalam klausa, seperti ini terjadinya. Kedua, di dalam proses tingkah laku terdapat verba petingkah yang direpresentasikan dalam bentuk interaksi verbal oleh pelibat di ruang sidang, yaitu rasa pedas dan iritasi. Ketiga, pada setiap proses tingkah laku ada elemen sirkumstan yang berfungsi sebagai objek atau keterangan. Sirkumstan ini menjelaskan konteks yang dibicarakan oleh partisipan pada proses tingkah laku. Hal tersebut digambarkan pada kata-kata, seperti sendiri.

Tabel 10. SPJM Sidang 4

\begin{tabular}{|c|c|c|}
\hline No & Proses Material & Fungsi \\
\hline & Saya & Petingkah \\
\hline Data 10 & Duduk & Proses tingkah: Material \\
\hline & Di dekat pak Saiful & Sirkumstan Tempat \\
\hline
\end{tabular}


Data 10 menunjukkan proses tingkah laku terdapat satu partisipan dilabeli petingkah. Petingkah bisa disamakan fungsinya sebagai subjek pada kata saya. Proses tingkah laku berperan sebagai verba tingkah material direalisasikan pada kata duduk. Sirkumstan berfungsi sebagai keterangan untuk menjelaskan lokasi tempat keberadaan seseorang dengan terdakwa.

Tabel 11. SPJM Sidang 9

\begin{tabular}{cll}
\hline No & \multicolumn{1}{c}{ Proses Material } & \multicolumn{1}{c}{ Fungsi } \\
\hline \multirow{2}{*}{ Data 11 } & Jessica & Petingkah \\
& Tidak panik & Proses tingkah: Mental \\
& Ketika melihat Mirna pingsan & Sirkumstan Cara \\
\hline
\end{tabular}

Data 11 menunjukkan proses tingkah laku dilakukan oleh Jessica dilabeli petingkah. Kata tidak panik diklasifikasikan pada proses tingkah laku sebagian memiliki sifat proses mental dilabeli proses tingkah laku mental, kata ketika meilhat Mirna pingsan bisa dikategorikan pada keterangan cara karena Mirna pingsan tidak menimbulkan reaksi pada Jessica dilabeli sirkumstan cara.

Tabel 12. SPJM Sidang 7

\begin{tabular}{|c|c|c|}
\hline No & Proses Material & Fungsi \\
\hline & Ahli & Petingkah \\
\hline Data 12 & $\begin{array}{l}\text { Berbicara tadi } \\
\text { Hak ingkar danat memberatkan terdakwa }\end{array}$ & $\begin{array}{l}\text { Proses tingkah:Verbal } \\
\text { Sirkumstan Kualitas }\end{array}$ \\
\hline
\end{tabular}

Data 12 menunjukkan proses tingkah laku ahli dilabeli petingkah. Kata berbicara tadi dikategorikan pada proses tingkah laku sebagian memiliki sifat proses verbal dilabeli proses tingkah laku verbal, kata hak ingkar dapat memberatkan terdakwa dapat dikategorikan pada frasa keterangan untuk menjelaskan bahwa hak ingkar dimaksud adalah tidak memberikan kesaksian sebenarnya di persidangan dilabeli sirkumstan kualitas.

Berdasarkan uraian analisis pada proses tingkah laku, terdapat empat kategori proses tingkah laku, yaitu fisiologi dan psikologi yang implikasinya sebagian memiliki sifat material, sebagian memiliki sifat proses mental, dan sebagian mempunyi sifat proses verbal. Hasil analisis data pada proses tingkah laku menunjukkan proses tingkah laku fisiologis memiliki sifat proses mental paling dominan ditemukan karena seakaan-akan terdakwa menyembunyikan kebenaran dengan tidak memberikan jawaban yang sejujurkan kepada hakim dan jaksa penuntut umum.

\section{Proses Relasional}

Proses relasional berkaitan dengan proses penghubung, penyandang penciri atau penanda, memiliki atribut dan penanda identitas (Halliday, 1985; Narlianti, 2015). Dalam bahasa Indonesia bentuk relasional tidak lazim digunakan, namun secara gramatika bentuk ini hadir. Proses relasional ini direalisasikan dengan verba menjadi, merupakan, kelihatan, berharga, bernilai, kedengaran, terdengar, menunjukkan, menandakan, memainkan, mempunyai, memiliki, dan lain-lain. Beberapa klasifikasi proses relasional sebagai berikut. 
a. Proses: Relasional: Atribut: Intensif

b. Proses: Relasional: Atribut: Sirkumstan

c. Proses: Relasional: Atribut: Kepemilikan

d. Proses: Relasional: Identifikasi: Intensif

e. Proses: Relasional: Identifikasi: Sirkumstan

f. Proses: Relasional: Identifikasi: Kepemilikan

Tabel 13. SPJM Sidang 1

\begin{tabular}{cll}
\hline No & \multicolumn{1}{c}{ Proses Material } & \multicolumn{1}{c}{ Fungsi } \\
\hline \multirow{4}{*}{ Data 13} & (apakah) & - \\
& Saudara & Penyandang \\
& Sebagai & Proses Relasiona: Atribut: Intensif \\
& Ahli patologi forensik & Atribut \\
\hline
\end{tabular}

Data 13 menunjukkan partisipan utama pada proses relasional identifikasi intensif dilabeli tanda. Tanda dapat disetarakan fungsinya sebagai subjek, seperti, saudara. Kedua, proses relasional identifikasi intensif menempati posisi sebagai verba, yaitu sebagai. Ketiga, nilai pada proses relasional identifikasi intensif dapat disetarakan posisi dan fungsinya sebagai objek, yakni ahli patologi forensik.

Tabel 14. SPJM Sidang 3

\begin{tabular}{cll}
\hline No & \multicolumn{1}{c}{ Proses Material } & \multicolumn{1}{c}{ Fungsi } \\
\hline \multirow{4}{*}{ Data 14 } & Sebetulnya yang berwenang & Tanda \\
& meminta pemeriksaan & Pdalah \\
& Penyidik Kapolri & Proses Relasiona: Identifikasi: Intensif \\
\hline
\end{tabular}

Data 14 menunjukkan kata sebetulnya yang berwenang meminta pemeriksaan dilabeli tanda dan disetarakan fungsinya sebagai subjek. Kata adalah dilabeli proses relasional identifikasi intensif dan disetarakan fungsinya sebagai verba atau kata kerja. Kata penyidik Polri dilabeli nilai dan disamakan fungsinya sebagai objek. Berdasarkan klasifikasi proses relasional hanya dua proses relasional paling dominan ditemukan, yaitu proses relasional atribut intensif dan proses relasional identifikasi intensif, sedangkan proses relasional empat lainnya tidak ditemukan. Uraian tersebut terdapat enam unsur proses dalam sistem transtivitas, yaitu proses material, proses mental, proses wujud, proses verbal, proses tingkah laku, dan proses relasional.

Tabel 15. Konfigurasi Penggunaan Sistem Transtivitas pada Medan Wacana

\begin{tabular}{clcc}
\hline Urutan & Transtivitas pada Medan Wacan & Jumlah & \% \\
\hline I & Proses Material & 5.822 & 45 \\
II & Proses Mental & 2.064 & 15 \\
III & Proses Wujud & 1.616 & 11 \\
IV & Proses Verbal & 1.501 & 11 \\
V & Proses Tingkah Laku & 1.345 & 10 \\
VI & Proses Relasional & 1.143 & 8 \\
& Jumlah & 13.813 & 100 \\
\hline
\end{tabular}




\section{PENUTUP}

Medan wacana meliputi tiga konstituen, yaitu proses, partisipan, dan sirkumstan. Ketiga konstituen unsur analisis pada teks dimaksudkan untuk menggambarkan aktivitas bahasa selama proses sidang peradilan. Analisis konstituen pertama adalah proses dalam sistem transtivitas mencakup proses utama dan proses tambahan. Tingkat dominasi penggunaan proses utama dan proses tambahan dalam struktur teks isi, khususnya mendatangkan enam saksi biasa dan delapan saksi ahli. Keseluruhan saksi biasa dan saksi ahli dihadirkan berjumlah empat belas sesi sidang SPJM. Empat belas sesi sidang SPJM tersebut mempunyai unsur proses berdominasi utama adalah proses material (45\%), proses mental (15\%), dan proses wujud (11\%). Kemudian unsur proses tingkat tambahan menunjukkan penggunaan proses verbal (11\%), proses tingkah laku (10\%), dan proses relasional (8\%). Dari keenam proses aktivitas bahasa didominasi oleh proses material.

\section{UCAPAN TERIMA KASIH}

Ucapan terima kasih kepada Ketua Yayasan STITNU Sakinah Dharmasraya Ibu Leli Arni, M.Si., Ketua STITNU Sakinah Dharmasraya Bapak Lesis Andre, M.Si., dan Ketua LP2M Stitnu Sakinah Dharmasraya Adi Fitra Adikos, M.Kom. yang telah memberikan dukungan material sehingga tulisan ini dapat dipublikasikan di jurnal ini. Semoga tulisan ini dapat melahirkan tulisan-tulisan yang berkualitas dan dimuat di jurnal bereputasi, baik nasional maupun internasional.

\section{DAFTAR PUSTAKA}

Creswell, J. W., \& Creswell, J. D. (2017). Research Design: Qualitative, Quantitative, and Mixed Methods Approaches (5th ed.). Thousand Oaks, CA: SAGE Publications.

Davis, H., \& Paul, W. (2010). Bahasa, Citra, Media. Yogyakarta: Jalasutra.

Genova, J. (1978). A Map of the Philosophical Investigations. Philosophical Investigations, $\quad 1(1), \quad 41-56 . \quad \mathrm{https}: / /$ doi.org/10.1111/j.14679205.1978.tb00179.x

Halliday, M. A. K. (1985). Introduction to Functional Grammar. USA: Edward Arnold.

Narlianti, N. P. V. (2015). Transitivitas dalam Teks Perda Kepariwisataan Kabupaten Tabanan. Journal of Language and Translation Studies, 1(2). Retrieved from https://ojs.unud.ac.id/index.php/ejl/article/view/23964

Satyawati, M. S., Fitri, N., Artawa, K., Sawirman, \& Udayana, N. (2020). Mental Process of Transivity in Indonesia Court Trial: A Forensic Linguistics. International Journal of Psychosocial Rehabilitation, 24(2), 4216-4222. https://doi.org/10.37200/IJPR/V24I2/PR200744

Sudarman, P. (2008). Menulis di Media Massa. Yogyakarta: Pustaka Pelajar. 